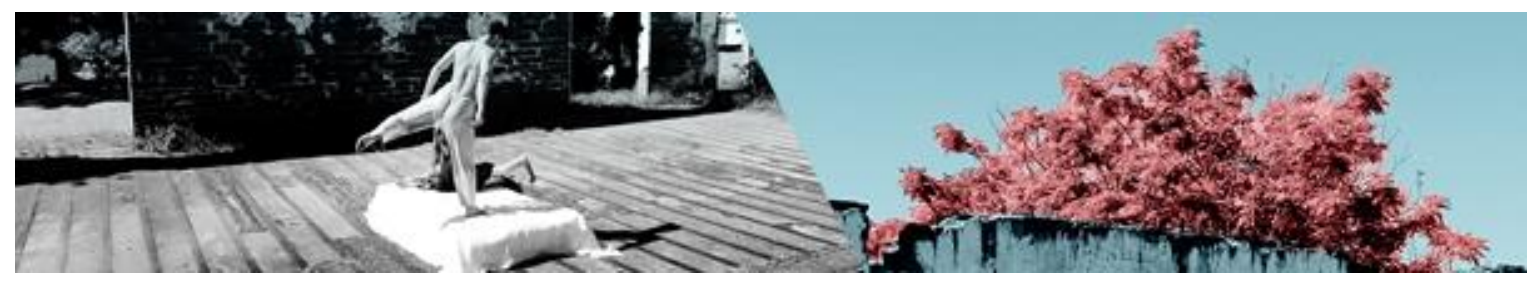

\title{
"TAMBORES DE VIDA: UMA PESQUISA DO TAMBOR DE CRIOULA DE JAMARY DOS PRETOS A PARTIR DO MÉTODO BAILARINO- PESQUISADOR-INTÉRPRETE"
}

\author{
Maria Julia Maranzato Alves Simão ${ }^{1}$ \\ Larissa Sato Turtelli2
}

Resumo: $O$ presente artigo traz a análise e as reflexões das experiências vividas dentro de um processo de pesquisa de campo realizada no quilombo Jamary dos Pretos (MA), através do método BPI (Bailarino-Pesquisador-Intérprete). Explanando o funcionamento do método diante da experiência da Intérprete, o artigo tem o objetivo de relatar e decodificar os movimentos presentes na dança do Tambor de Crioula, manifestação popular tradicional na comunidade pesquisada, além de contar com um breve relato sobre o processo criativo resultante dessa pesquisa.

Palavras-chave: Tambor de Crioula; Método BPI; Dança do Brasil.

\section{"DRUMS OF LIFE: A SEARCH OF JAMARY'S CREOLE DRUM FROM THE BLACKS-DANCER-RESEARCHER-INTERPRETER METHOD"}

\begin{abstract}
This article brings an analysis and reflections of the experiences lived in a process of field research in the quilombo Jamary dos Pretos (MA, Brazil) based on the BPI Method (DancerResearcher-Performer). Aiming to explain the Method from the researcher's experience within it, this article reports and decodes Tambor de Crioula's dance movements, a popular and tradicional manifestation in the community in which the research was taken, and also briefly reports the resulting creative process.
\end{abstract}

Keywords: Drums of Crioula; BPI method; Brazil dance.

\section{Introdução}

O presente artigo $^{3}$ trata de uma investigação artística realizada a partir do eixo Co-habitar com a Fonte do método Bailarino-Pesquisador-Intérprete (BPI), tendo

\footnotetext{
1 Maria Julia M. Alves Simão é bailarina e professora de dança, participa do Grupo de Pesquisa Bailarino -Pesquisador- Intérprete (BPI) e Dança do Brasil. Graduada em Dança e Mestra em Artes da Cena, ambos pela pela Universidade Estadual de Campinas (Unicamp - SP) E-mail: mimaranzatoalves@gmail.com

${ }^{2}$ Larissa Sato Turtelli é Bailarina, intérprete e diretora no método Bailarino-Pesquisador-Intérprete. Professora Doutora do Instituto de Artes da Universidade Estadual de Campinas (Unicamp-SP), com atuação na Graduação em Dança e na Pós-Graduação em Artes da Cena. Chefe do Departamento de Artes Corporais do Instituto de Artes da Unicamp. E-mail: L.turtelli@iar.unicamp.br
}

3 Este artigo está relacionado à pesquisa de mestrado da primeira autora: "Dançar para as Nossas Senhoras: um estudo na confluência de coabitares do método BPI (Bailarino-Pesquisador-Intérprete" (2015-2017), com orientação da Profa. Dra. Larissa Turtelli, desenvolvida no Programa de PósGraduação em Artes da Cena da UNICAMP (Universidade Estadual de Campinas).

SIMÃO, Maria Julia Maranzato Alves; TURTELLI, Larissa Sato. "Tambores de vida: uma pesquisa do Tambor de Crioula de Jamary dos Pretos a partir do método bailarino-pesquisador-intérprete". . Revista da FUNDARTE, Montenegro, p.91-111, ano 19, ํㅡ 37, Janeiro/Março.

Disponível em: http://.seer.fundarte.rs.gov.br/index.php/RevistadaFundarte/index> 30 de março de 2019. 


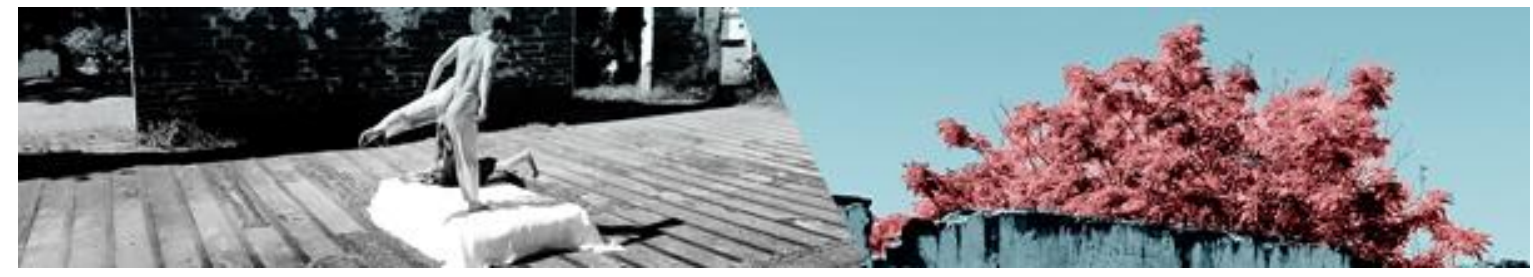

como foco uma pesquisa de campo na comunidade Jamary dos Pretos, no Maranhão, durante a festa de Nossa Senhora das Graças de dezembro de 2015, na qual, além dos contextos do cotidiano e de preparações para o evento, foram observadas as ladainhas, o hasteamento e retirada de mastro, a procissão e o Tambor de Crioula desta comunidade. Após o término dessa pesquisa de campo, empreendida pela primeira autora deste artigo, foi investigado em estúdio, junto a sua orientadora - e segunda autora - o que esse trabalho mobilizou sensível e artisticamente em seu corpo.

A partir da experiência da intérprete em pesquisa de campo e das análises e reflexões efetivadas juntamente com sua orientadora, esse trabalho expõe as decodificações dos movimentos observados na dança do Tambor de Crioula da comunidade Jamary dos Pretos. Para essa análise corporal foi utilizada como base a Estrutura Física e Anatomia Simbólica do método BPI, bem como a Técnica dos Sentidos do mesmo método.

A comunidade quilombola de Jamary dos Pretos, localizada a $470 \mathrm{~km}$ de São Luís (MA), tem uma média de quinhentos moradores nos seus seis mil hectares, de acordo com o INCRA (Pinheiro, 2015). Não se sabe ao certo o ano de formação do quilombo. Segundo Pinheiro (2015, p. 2): "A referência mais antiga ao quilombo de Jamary em documentação oficial data de 1841 e consta em um auto de apreensão de escravos fugidos".

A chegada ao quilombo se dá através de $8 \mathrm{~km}$ partindo da BR, em estrada de terra curvilínea, aberta pelos próprios moradores no meio da mata. Dentro do quilombo existem pequenos "bairros" mais isolados: Bela Vista, Arrudá e Cajual. Essas localidades ficam mais afastadas da sede do Jamary e, em geral, vivem nelas alguns núcleos de uma mesma família.

A maioria dos quilombolas tem suas casas construídas ao redor da sede, que está localizada na parte central do quilombo. Trata-se de um barracão com chão de cimento, cercado por alguns pilares que dão sustentação ao telhado. Ao seu lado fica a capela, atrás se encontra a escola e, à sua frente, o campo de futebol. Ao redor dessa parte central ficam as casas, que foram construídas espaçadas umas 


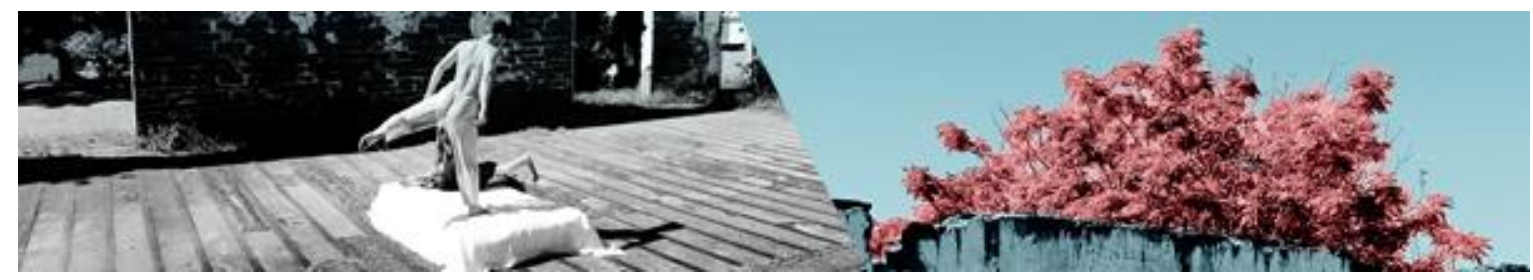

das outras, possibilitando que entre elas se instalassem novas edificações: alguns bares, uma igreja evangélica e pequenas vendas.

O solo das ruas do quilombo é de terra vermelha, que se mistura com gramados e grandes árvores existentes no local. No período em que a primeira autora esteve no Jamary, era época de seca. Portanto, tudo aparentava estar ressecado: a terra levantava poeira, os gramados tinham um tom de verde amarelado e apenas algumas árvores estavam com as folhas verdes.

A maioria das casas do quilombo já é cimentada. São pequenas e simples, com chão de cimento e um quintal próprio, delimitado por cercas de arame. Ainda existem algumas casas feitas de barro e outras que ainda não têm o acabamento completo - possuem algumas partes de barro ou de cimento.

A energia elétrica chegou para os jamarizeiros em 2006, apenas dentro de suas casas; nas ruas do quilombo não há postes de iluminação. Portanto, mesmo com energia elétrica, o escuro ainda predomina nas ruas da comunidade no período noturno.

Devido ao histórico isolamento geográfico do quilombo, a cultura de subsistência sempre foi comum aos moradores do lugar. A criação de animais faz parte dessa cultura - cria-se gado, galinhas e porcos, todos soltos, circulando livremente pelo quilombo. Na época de cheia (inverno) é quando se mata mais bichos para alimentação, pois as chuvas fazem o rio subir, muitas vezes alagando a ponte que existe na estrada e dá acesso ao quilombo, deixando os moradores ilhados e, consequentemente, impossibilitados de comprar carne na cidade de Turiaçu.

Antigamente, plantava-se "mandioca, milho, feijão, batata, abóbora, gergelim, cará e árvores frutíferas como mangueiras, cajueiros, mamoeiros e bananeiras, preservando-se palmeirais e madeiras de lei" (Odwyer, 2002, p. 183). Ainda existem plantações dessas culturas no quilombo, mas a chegada da eletricidade e os recursos obtidos com programas sociais têm modificado esse cenário.

Atualmente, os jamarizeiros têm a possibilidade de comprar aparelhos domésticos como geladeira, TV, fogão e máquina de lavar roupa, além de Tambor de Crioula de Jamary dos Pretos a partir do método bailarino-pesquisador-intérprete". . Revista da FUNDARTE, Montenegro, p.91-111, ano 19, no 37, Janeiro/Março.

Disponível em: http://.seer.fundarte.rs.gov.br/index.php/RevistadaFundarte/index> 30 de março de 2019. 


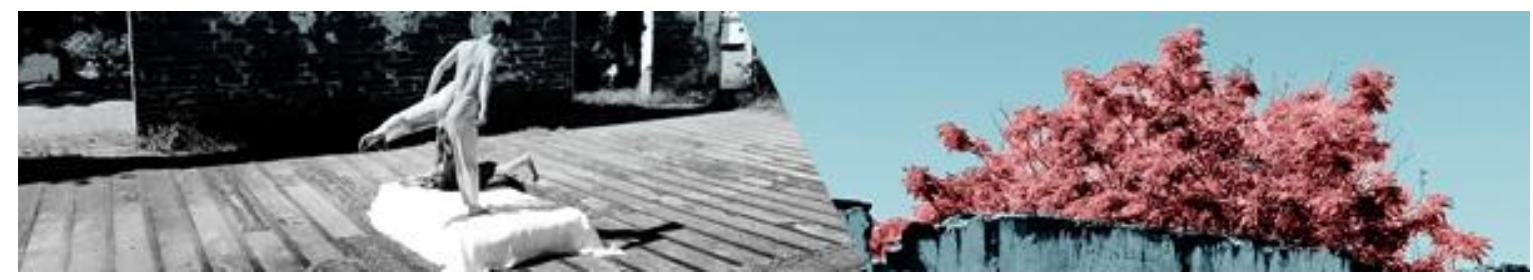

brinquedos, remédios e alimentos industrializados, como refrigerantes, salgadinhos e bolachas, aos quais até bem pouco tempo não tinham acesso. Com isso, o interesse pelo roçado, entre os quilombolas, tem diminuído.

\section{O Tambor de Crioula}

A festa de Nossa Senhora das Graças tem início com o Tambor de Crioula no dia 29 de dezembro, e termina no dia primeiro de janeiro, com a retirada do mastro. Assim, pode-se entender que a duradoura festa é um acontecimento de suma importância para os moradores do Jamary: "Todos são unânimes em descrever a grandeza dessa festa, que dura até quatro dias, vindo gente de todos os povoados próximos" (Odwyer 2002, p.200). A festa apresenta diversas dinâmicas: a ladainha, o Tambor de Crioula, o hasteamento e retirada do mastro e a procissão.

Muitos moradores do Jamary, com os quais a pesquisadora conversou sobre a origem do Tambor de Crioula, disseram que este vem do período da escravização. segundo eles, tocava-se o Tambor para fazer barulho e algazarra, o que chamava a atenção dos senhores de escravos enquanto facilitava a fuga de alguns deles.

Odwyer (2002, p.204) apresenta outra versão sobre a origem do Tambor de Crioula, ao relatar que:

[...] fomos apresentados à Sra. Maria Borges, moradora do Jamary há 90 anos, que associou esse festejo à Lei Áurea: foi assim no dia da libertação. Papai contava que os pretos fizeram tambor nas fazendas, para comemorar a libertação, e cantaram se despedindo até de manhã. Quando o dia amanheceu, cadê os pretos? Caíram todos no mundo.

Para Ferreti (1981), o Tambor de Crioula era realizado por motivos de pagamento de promessa, datas comemorativas (aniversários, despedidas e dias santos) e até para reunião de amigos.

Os moradores do Jamary dos Pretos, enquanto a dança do Tambor de Crioula estava ocorrendo durante a Festa de Nossa Senhora das Graças, contaram para a primeira autora que, ali, naquele momento do Tambor, seus antepassados também estavam presentes na festa: "eles puxam as pessoas para dançar, dançam com elas e, muitas vezes, conduzem os quilombolas durante o ato". 


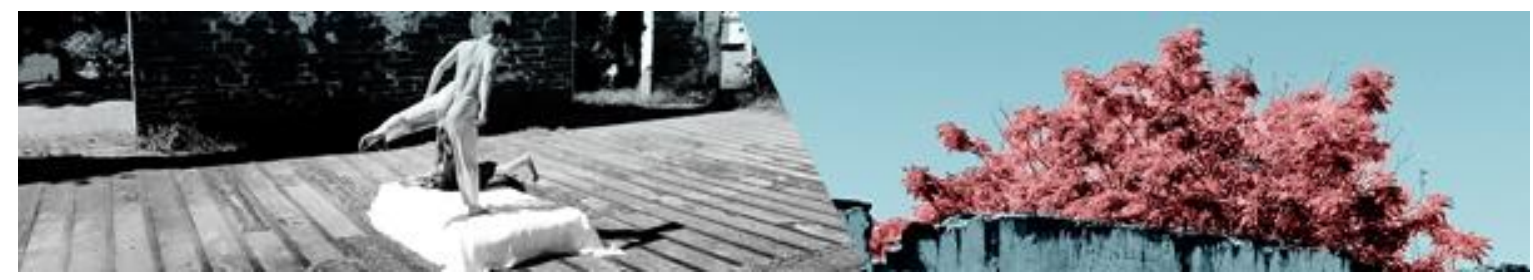

Em vista desses dados e da vivência da primeira autora durante o Tambor de Crioula, foi constatado que esse é um momento de viva conexão das pessoas da comunidade com a história do quilombo e com os antepassados que viveram ali. Além disso, notou-se a alegria dos jamarizeiros e sua necessidade premente de dançar o Tambor de Crioula, como se aquela dança os renovasse, desse uma nova energia para aqueles corpos. O momento do Tambor de Crioula era um respiro em meio à dura realidade que é a vida no quilombo:

É de lá que o tambor rufa o inconformismo, desdenha da mesmice, do padrão. É lá que a toada ignora a submissão, que a fogueira consome a dor e transforma-a em força radiante. É lá que os pés das coreiras vão sedimentando um outro lugar e seus gritos ultrapassam fronteiras. (CORDEIRO, 2006, p. 36).

O sentido percebido no Tambor de Crioula do Jamary, durante a pesquisa, é ressaltado por Santos (in Boletim, 1995, p.3): "Nas cidades e povoados do interior do Estado, o tambor de crioula tem uma força vital".

É comum que cada comunidade ou grupo praticante do Tambor de Crioula tenha sua referência quanto à origem do Tambor:

[...] em muitos casos não há uma narrativa geral sobre o tambor e sua origem ancestral, e sim a história específica de determinado grupo de tambor, demonstrando que, naquilo que costumamos chamar de cultura popular, há espaço para a individualidade, a diferenciação. (BARROS, 2006, p. 42).

O que se pode afirmar é que se trata de uma manifestação originalmente negra que remete ao período da escravização no Brasil:

Embora não seja possível apurar com exatidão as origens históricas do tambor de crioula, na memória dos brincantes mais velhos e em fontes históricas, podem se encontrar registradas, desde o século XIX, referências a cultos religiosos concebidos como formas de lazer, devoção e resistência. (FIGUEIREDO e OLIVEIRA, 2012).

SIMÃO, Maria Julia Maranzato Alves; TURTELLI, Larissa Sato. "Tambores de vida: uma pesquisa do Tambor de Crioula de Jamary dos Pretos a partir do método bailarino-pesquisador-intérprete". . Revista da FUNDARTE, Montenegro, p.91-111, ano 19, no 37, Janeiro/Março.

Disponível em: http://.seer.fundarte.rs.gov.br/index.php/RevistadaFundarte/index> 30 de março de 2019. 


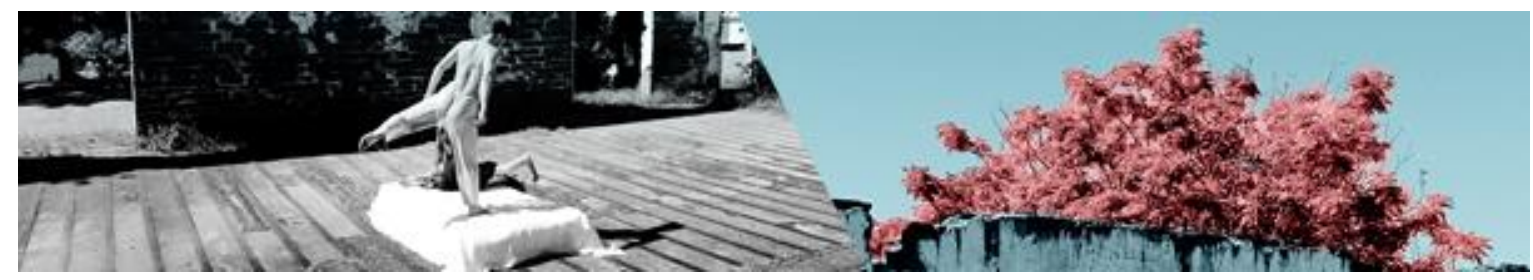

O Tambor de Crioula acontece num formato de roda, na qual os homens tocam os tambores e as mulheres compõem o restante da roda e entram no meio desta para dançar. Essa estrutura foi observada na pesquisa de campo realizada no quilombo Jamary dos Pretos e é também citada por Odwyer (2002, p.202) e por Ferreti (1981, p.6).

Dentro da dança do Tambor de Crioula acontece a punga, movimento no qual a mulher que está dançando no centro da roda bate com seu umbigo no de outra mulher que está em volta do círculo. Tal movimento indica que a mulher que recebeu a punga deve entrar na roda para dançar. Rocha (2014, p. 374) descreve: "A punga, então, varia de dançante para dançante, sendo caracterizada pelo encontro, uma rápida batida entre as barrigas das mulheres que darão, dessa forma, a pungada, ou seja, a umbigada".

A punga também pode ser dada para os tamboreiros. Nessa estrutura, a mulher dança bem próxima aos tambores, e, em seus movimentos, ela apresenta uma acentuação do umbigo direcionada aos instrumentos e a seus tocadores, fazendo esse movimento para cada um dos tambores presentes.

O gesto da umbigada é antigo e há registros de que tenha sido trazido para o Brasil juntamente com os negros escravizados. Tal movimento é indicado por alguns autores como um gesto ligado à sexualidade, principalmente por ser "característico de danças de lúdica amorosa banto-africanas, por vezes associadas às cerimônias de noivado: o lembamento" (DIAS, 2001, p.10).

O som do Tambor de Crioula fica a cargo dos tamboreiros, nome dado aos homens que tocam esses instrumentos. Para isso são utilizados três tambores: um recebe o nome de tambor grande, ou rufador, e os outros dois menores são chamados de meião (ou socador) e crivador (ou pererenga). Dessa maneira, "O grande puxa e o meião (tambor do meio), acompanha os outros" (SANTOS, 1995, p.3).

Os tambores, que são feitos de troncos de árvore, apresentam um afunilamento em uma ponta e são cobertos com couro animal em outra. O tambor grande do Jamary dos Pretos tem mais de um metro de comprimento e é coberto Tambor de Crioula de Jamary dos Pretos a partir do método bailarino-pesquisador-intérprete". . Revista da FUNDARTE, Montenegro, p.91-111, ano 19, no 37, Janeiro/Março.

Disponível em: http://.seer.fundarte.rs.gov.br/index.php/RevistadaFundarte/index> 30 de março de 2019. 


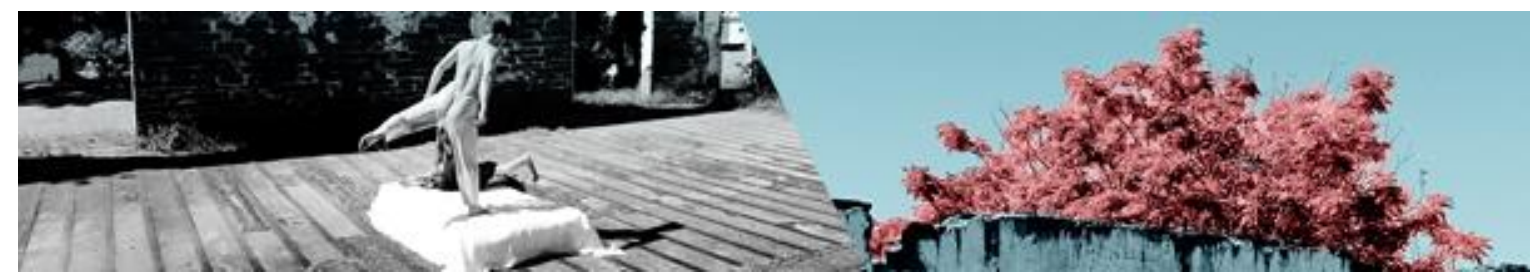

com couro de vaca. Já os tambores menores são mais curtos e têm um menor diâmetro; sua cobertura é feita com couro de cobra.

No Tambor de Crioula do Jamary, os homens se revezam para tocar o instrumento: os três tambores ficam na posição horizontal e os tamboreiros se acomodam como se estivessem sentados em cima deles para tocá-los. O toque se dá num ritmo acelerado. Os tambores menores são mais agudos e seguem o toque do tambor grande, que é tocado também por um quarto homem, na parte do tronco, com dois pedaços de madeira que remetem a baquetas. $O$ toque desse quarto homem é mais acelerado e agudo que o som dos demais tambores. Ferreti e Sandler (1995, p.1) descrevem essa mesma estrutura em suas pesquisas, com a diferença do tambor grande ficar de pé:

O tambor grande é amarrado à cintura do tocador chefe, de pé, preso entre suas pernas. Os dois menores são apoiados no chão, sobre um tronco, com os tocadores sentados como os tambores entre suas pernas. Um ajudante, agachado atrás do tambor grande percute as duas matracas, produzindo interessantes variações de acompanhamento.

$\mathrm{O}$ ato dos tocadores de sentar sobre os tambores e de nomeá-los, bem como a sua maneira de tocar os instrumentos e de afiná-los, não são características inerentes apenas ao Tambor de Crioula, ou à comunidade Jamary dos Pretos. Pereira (2005, p. 366) ressalta que "chama a atenção à similaridade das formas de alguns tambores africanos e brasileiros, bem como o hábito de nomeá-los, de utilizalos em números de três, de sentar sobre eles durante os rituais e a maneira de afinálos".

SIMÃO, Maria Julia Maranzato Alves; TURTELLI, Larissa Sato. "Tambores de vida: uma pesquisa do Tambor de Crioula de Jamary dos Pretos a partir do método bailarino-pesquisador-intérprete". . Revista da FUNDARTE, Montenegro, p.91-111, ano 19, n37, Janeiro/Março.

Disponível em: http://.seer.fundarte.rs.gov.br/index.php/RevistadaFundarte/index> 30 de março de 2019. 

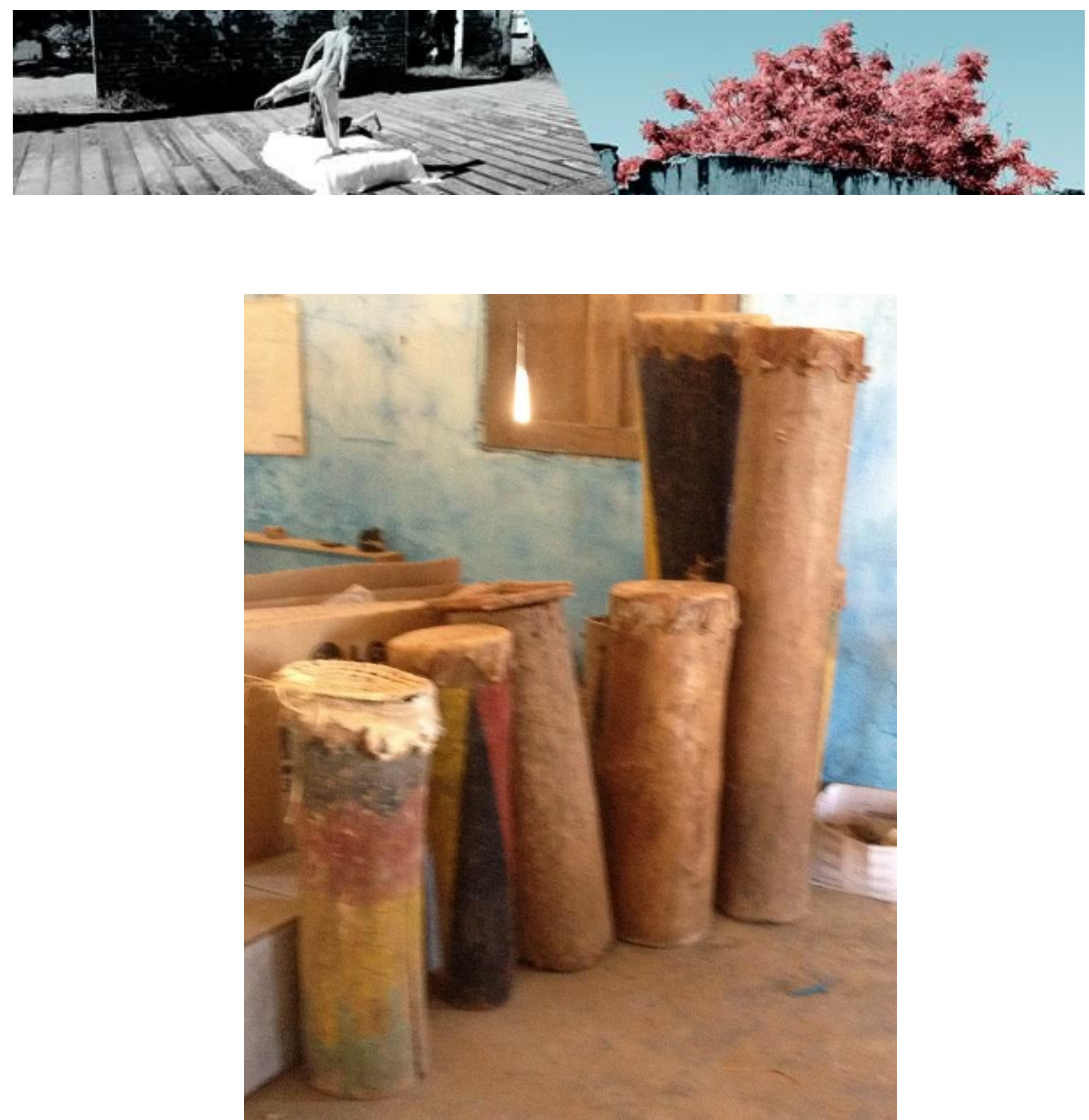

Figura 1 - Tambores de Crioula no altar da antiga capela de Jamary dos Pretos (MA), foto do arquivo pessoal da pesquisadora, 2015.

A relação dos jamarizeiros com o Tambor vai além do ato de tocar o instrumento. Quando não estão sendo usados, os tambores ficam na capela do quilombo, e não é qualquer pessoa que aguenta tocá-los. As mãos dos tamboreiros ficam machucadas, sangram e adquirem bolhas. Porém, eles parecem não se importar com isso, passando a impressão de que a força que o tambor traz é o mais importante naquele momento.

Antes de serem tocados, os tambores são afinados próximos a uma fogueira para que o couro fique mais esticado. Durante a festa de Nossa Senhora das Graças, enquanto os instrumentos estavam sendo aquecidos, alguns tamboreiros se aproximavam e os tocavam, colocando os ouvidos próximos a eles, ouvindo o som com atenção para checar se estavam afinados.

SIMÃO, Maria Julia Maranzato Alves; TURTELLI, Larissa Sato. "Tambores de vida: uma pesquisa do Tambor de Crioula de Jamary dos Pretos a partir do método bailarino-pesquisador-intérprete". . Revista da FUNDARTE, Montenegro, p.91-111, ano 19, ํㅡ 37, Janeiro/Março.

Disponível em: http://.seer.fundarte.rs.gov.br/index.php/RevistadaFundarte/index> 30 de março de 2019. 


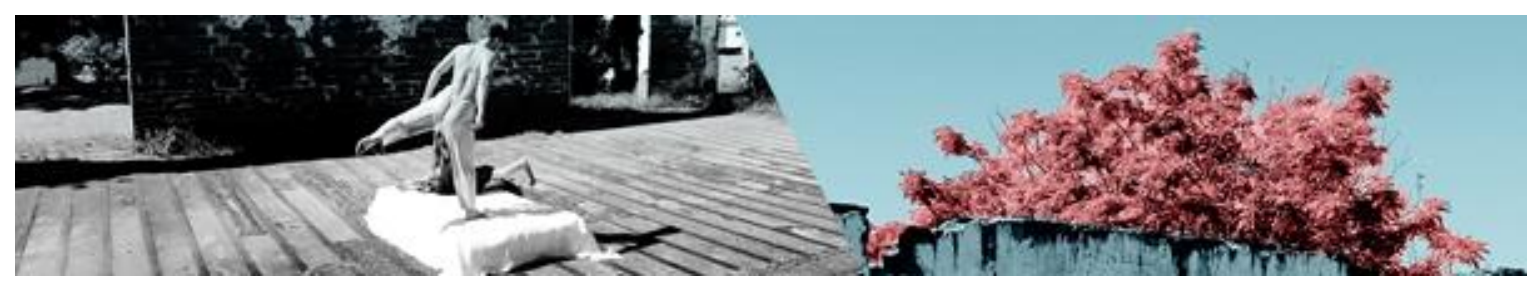

Os cantos do Tambor de Crioula no quilombo são realizados normalmente por Seu Antônio Carneiro, um senhor de idade, nascido e crescido no Jamary. Segundo ODWYER (2002, p. 203), as letras e os versos cantados no Tambor:

[...] referem-se aos lugares comuns no imaginário do povoado: a mata e seus encantamentos, as mulheres e sua dança, a busca da liberdade, a alegria de conviver com os amigos, de cantar, dançar e viver, o trato com o gado e outras atividades do cotidiano de seus moradores.

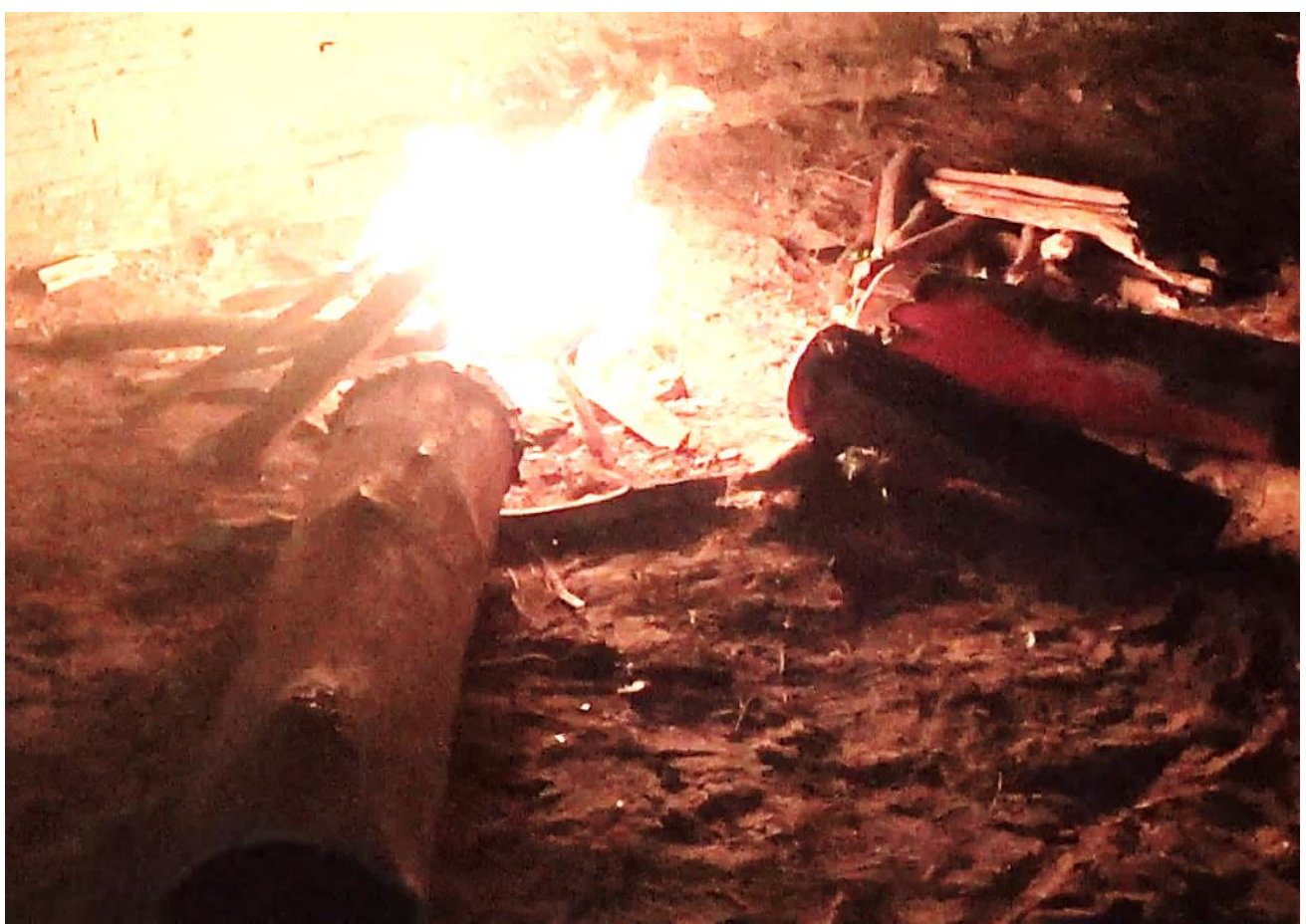

Fig. 2- Tambores de Crioula sendo afinados no fogo, em Jamary dos Pretos (MA). Foto do arquivo pessoal da pesquisadora, 2015.

\section{O método BPI enquanto base da pesquisa}

O método BPI, criado pela $\operatorname{Prof}^{\mathrm{a}} \mathrm{Dr}^{\mathrm{a}}$ Graziela Rodrigues, é formado por três eixos (Rodrigues, 2003): Inventário no corpo, Co-habitar com a Fonte e Estruturação da Personagem. Esses eixos são desenvolvidos a partir de cinco ferramentas:

SIMÃO, Maria Julia Maranzato Alves; TURTELLI, Larissa Sato. "Tambores de vida: uma pesquisa do Tambor de Crioula de Jamary dos Pretos a partir do método bailarino-pesquisador-intérprete". . Revista da FUNDARTE, Montenegro, p.91-111, ano 19, oㅡ 37, Janeiro/Março.

Disponível em: http://.seer.fundarte.rs.gov.br/index.php/RevistadaFundarte/index> 30 de março de 2019. 


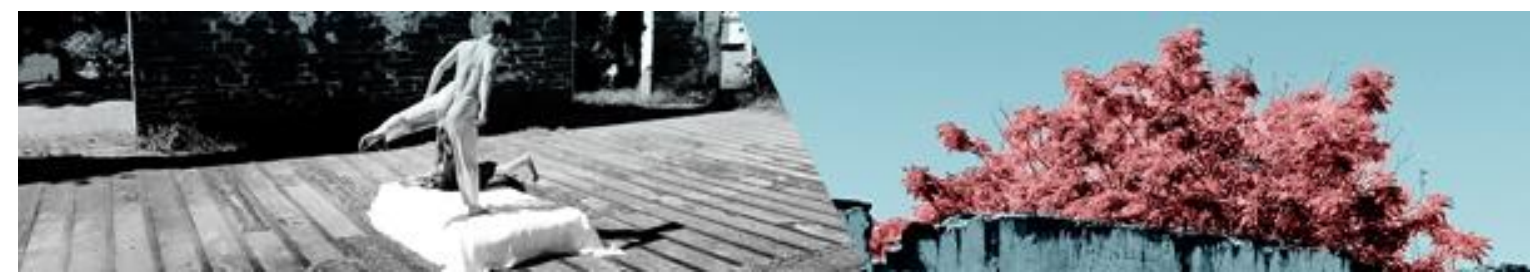

Técnica de Dança, Técnica dos Sentidos, Laboratórios dirigidos, Pesquisas de Campo e os Registros, que auxiliam o intérprete na "realização corporal que irá produzir uma Arte gerada no cerne do corpo da pessoa" (Rodrigues, 2010, p. 1).

O Inventário no corpo é o primeiro eixo a ser trabalhado no método. Nele, o intérprete realiza uma pesquisa em torno de seu histórico familiar e cultural, a fim de auxiliar o despertar de sua memória corporal, contribuindo assim para o reconhecimento dos conteúdos culturais e sensíveis presentes em seu corpo, como mostra Rodrigues (2003, p. 79): "Nessa fase introdutória, a memória do corpo é ativada, possibilitando que ao longo do processo ocorra uma autodescoberta quanto às próprias sensações, sentimentos, história cultural e social".

Como parte fundamental do desenvolvimento no método e da compreensão do Inventário no Corpo, ocorre o trabalho da Técnica de Dança do método BPI, chamada de Estrutura Física e Anatomia Simbólica. Aspectos essenciais dessa técnica são trabalhados em todo o corpo, usando, por exemplo, diferentes gradações de enraizamento dos pés, sendo elas raízes soltas, médias ou profundas; a atuação dos diferentes apoios dos pés, podendo ser grandes apoios (metatarso, calcanhar bordas internas ou externas) ou pequenos apoios; a pelve pesando para o chão com a imagem de um prolongamento do cóccix que vai até o solo; os movimentos com o quadril que desenham o símbolo do infinito $(\infty)$; a soltura e alternância das escápulas; a região do esterno articulada até os braços como um estandarte, construindo um eixo mastro flexível; e as posturas variando entre perpendicular, abaulada, paralela e com o esterno direcionado para o céu.

As diferentes movimentações dos pés são particularmente importantes dentro dessa técnica de dança do método $\mathrm{BPI}$, já que a partir dos pés todo o corpo se estrutura, e porque muitas vezes eles anunciam o conteúdo simbólico que se manifestará no corpo. As diferentes gradações de esforço empregado pelos pés em direção ao solo ganham imagem de raízes que se estendem das solas dos pés e penetram o solo em diferentes profundidades. Quando os pés estão bem conectados ao chão, com a intenção de penetrá-lo em profundidade, obtêm-se as raízes profundas. As raízes médias se dão quando as solas dos pés penetram o solo 


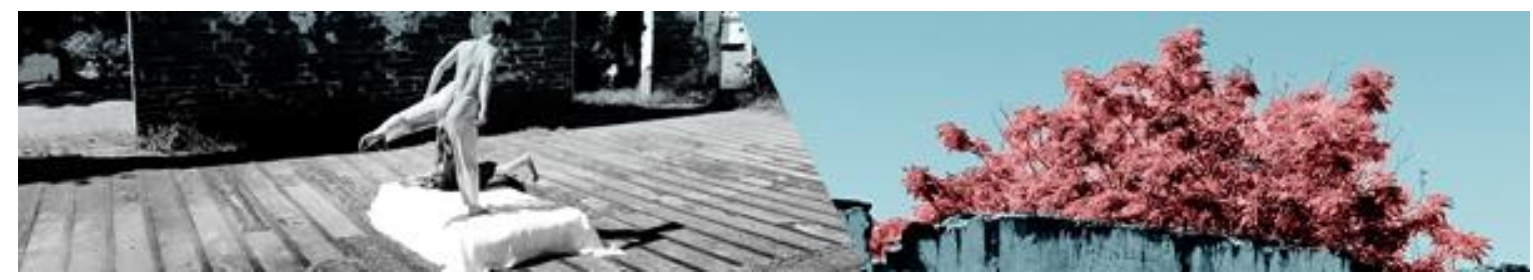

além da superfície, mas permitem mobilidade e destreza. Já as raízes soltas aparecem quando o contato dos pés com o chão é superficial: uma sutilização dos apoios dos pés (Rodrigues 2005, p. 46).

A Estrutura Física também auxilia o intérprete a se preparar para o próximo eixo do método, o Co-habitar com a Fonte. O enraizamento adquirido na Estrutura Física amplia a percepção do corpo do bailarino e de seus sentidos, deixando-o, assim, aberto e sensível, pronto para coletar dados sobre si e sobre o ambiente.

A Estrutura Física é usada também para que o bailarino-pesquisador-intérprete decodifique a movimentação vista em campo. Através dela, é possível analisar a penetração dos pés no solo, o direcionamento e os movimentos do sacro e da parte superior da coluna, a formação do eixo-mastro, as gradações de tônus, os pulsos e impulsos, dentre outros.

No eixo Co-habitar com a Fonte, o intérprete escolhe uma pesquisa de campo a ser realizada. Sua escolha - o quê e onde pesquisar - é determinada por suas próprias motivações internas (RODRIGUES, 2003, p.106). No caso desta pesquisadora, a motivação de investigar o quilombo Jamary dos Pretos e o Tambor de Crioula, dançado no Quilombo, na festa de Nossa Senhora das Graças, foi decorrente de um processo anteriormente realizado pela primeira autora desse artigo e com direção da segunda, no qual a dinâmica da personagem que dançava e zelava por Nossa Senhora foi muito forte.

Dentro do método $\mathrm{BPI}$, a relação durante a pesquisa de campo é delicada e deve ser estabelecida aos poucos, com respeito e sem pressa, buscando gradativamente uma sintonia com o outro. Deve-se respeitar a abertura que o pesquisado está dando a cada momento, observando os indícios dados por ele. Rodrigues et al. (2016, p. 559) reforçam sobre a relação entre pesquisador e pesquisado:

$\mathrm{Na}$ perspectiva do método $\mathrm{BPI}$, se não há uma abertura da parte do pesquisado, se ele não teve empatia e sintonia com o pesquisador e o pesquisador com ele, se não há uma reciprocidade, este não será um campo de pesquisa que terá continuidade, deve-se procurar outro local. As próprias pessoas pesquisadas são quem atestam se houve ou não essa reciprocidade, através dos seus gestos, das suas falas e das suas atitudes

SIMÃO, Maria Julia Maranzato Alves; TURTELLI, Larissa Sato. "Tambores de vida: uma pesquisa do Tambor de Crioula de Jamary dos Pretos a partir do método bailarino-pesquisador-intérprete". . Revista da FUNDARTE, Montenegro, p.91-111, ano 19, ํo 37, Janeiro/Março.

Disponível em: http://.seer.fundarte.rs.gov.br/index.php/RevistadaFundarte/index> 30 de março de 2019. 


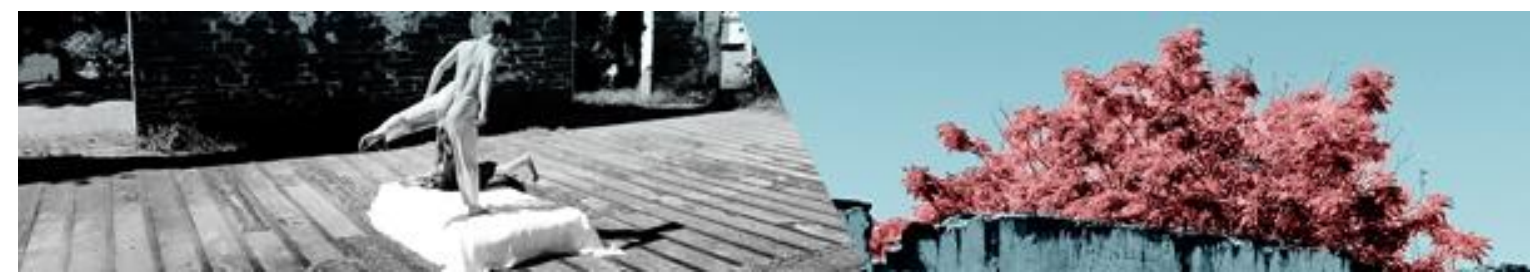

de abertura e acolhimento em relação ao pesquisador. $O$ franco interesse do pesquisador pelo pesquisado muitas vezes faz este sentir-se reconhecido por aquilo que vive.

Com o desenvolvimento das relações em campo, o pesquisador começa a sentir-se parte do local e aceito pelos pesquisados. Ele vive uma relação de alteridade, na qual não cabem idealizações das pessoas pesquisadas. São feitas preparações, antes de ir a campo, que envolvem trabalhos práticos e reflexivos para que o pesquisador busque um olhar consciente das relações de poder, e que não romantize as realidades com as quais entra em contato.

O foco da pesquisa de campo no eixo Co-Habitar com a Fonte são as relações interpessoais. Antes do intérprete ir para a pesquisa, é feita uma preparação que envolve um trabalho corporal e emocional, bem como reflexões a respeito de diversos aspectos envolvidos nessa relação com os pesquisados, como as relações de poder, os limites e os estados de receptividade. As condições de atenção e concentração trabalhadas ao longo de todo o processo no método BPI devem ser as melhores possíveis nesse momento. $O$ intérprete em campo mantém o seu foco nas relações com os pesquisados, ao mesmo tempo em que está atento às suas próprias sensações e sentimentos. (Rodrigues et al. 2016, p.557-558).

Durante o Co-habitar com a Fonte são realizados registros da pesquisa que são os diários de campo, nos quais o bailarino-pesquisador-intérprete documenta as vivências da pesquisa de campo, bem como suas impressões pessoais e, possivelmente, registros audiovisuais. Esse material é posteriormente analisado e, em alguns casos como o desta pesquisa, as filmagens são utilizadas para decodificar as dinâmicas e a Estrutura Física presentes nas movimentações pesquisadas.

A pesquisa de campo é intercalada com os laboratórios dirigidos. Os dojos ${ }^{4}$, que acolhem as movimentações carregadas de sensações e imagens, emanam do corpo do intérprete, fruto da sua interação com o campo. Os laboratórios são

4 "Os estudos de imagem corporal consideram ao redor do corpo, uma extensão do corpo, por ser uma esfera de sensibilidade especial. Segundo Paul Schilder, do ponto de vista psicológico, os arredores do corpo são animados por ele. Em dança, este espaço significa um espaço pessoal que, segundo Laban, é chamado Kinesfera. Em tradições orientais este espaço em torno do corpo é chamado de dôjo, espaço este que o guerreiro deve cuidar para que não seja invadido pelo inimigo por ser parte de seu corpo". (RODRIGUES e MULLER, 2006, p.136).

SIMÃO, Maria Julia Maranzato Alves; TURTELLI, Larissa Sato. "Tambores de vida: uma pesquisa do Tambor de Crioula de Jamary dos Pretos a partir do método bailarino-pesquisador-intérprete". . Revista da FUNDARTE, Montenegro, p.91-111, ano 19, oㅜ 37, Janeiro/Março.

Disponível em: http://.seer.fundarte.rs.gov.br/index.php/RevistadaFundarte/index> 30 de março de 2019. 


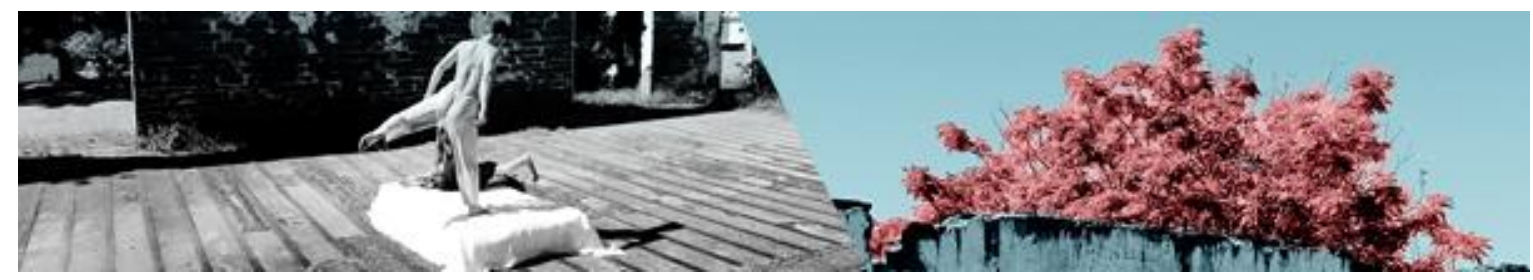

elaborados pelo diretor, com o intuito de que ocorra o reconhecimento do material de pesquisa no corpo do intérprete. Como parte desse eixo do Co-habitar com a Fonte podem também ser estudadas no corpo e experimentadas as movimentações vividas na pesquisa de campo. Este eixo "possibilita uma rica interação entre corpos. [...] O pesquisador, ao estabelecer uma fina sintonia no contato com o outro, poderá sintonizar-se consigo mesmo e se conhecer" (RODRIGUES, 2003, p. 105).

Nos laboratórios dirigidos, além da Estrutura Física, utiliza-se a Técnica dos Sentidos, que ocorre no corpo do intérprete através de "circuitos de imagens/sensações/emoções/movimentos, não importando a ordem na qual eles se apresentem" (RODRIGUES, 2010, p.2). Tal circuito permite que o intérprete entre em contato com seus conteúdos corporais, reconhecendo-os e os integrando em sua dança.

O terceiro eixo do método BPI, a Estruturação da Personagem, tem início quando, nos laboratórios dirigidos do Co-habitar com a Fonte, aparecem imagens de paisagens que começam a se repetir e a se ligar à imagem de um "alguém" que habita nelas. Aparecem, então, movimentos resultantes de imagens corporais que configuram o corpo de alguém imaginário. Assim, uma personagem é criada, fruto das relações pessoais do intérprete com o campo pesquisado. Entende-se, portanto, que: "A personagem emerge do Co-habitar com a Fonte e do que essa vivência despertou na própria pessoa." (RODRIGUES, 2003, p. 121).

A personagem é fruto da vivência de vários corpos que, durante os laboratórios de movimento, encontram uma maneira de se nuclear, permitindo, assim, chegar ao "momento em que ocorre a fusão dos corpos, que pronuncia uma personagem" (op.cit., p. 130). A chamada Incorporação da personagem no BPI ocorre quando "a pessoa alcança uma integração das suas sensações, das suas emoções e das suas imagens, vindas até então soltas e desconectadas" (RODRIGUES, 2003, p.124).

\section{O Tambor de Crioula de Jamary dos Pretos e seus movimentos}

Em seu parecer técnico, o IPHAN (2007) ressalta a carência bibliográfica relacionada ao Tambor de Crioula:

SIMÃO, Maria Julia Maranzato Alves; TURTELLI, Larissa Sato. "Tambores de vida: uma pesquisa do Tambor de Crioula de Jamary dos Pretos a partir do método bailarino-pesquisador-intérprete". . Revista da FUNDARTE, Montenegro, p.91-111, ano 19, № 37, Janeiro/Março.

Disponível em: http://.seer.fundarte.rs.gov.br/index.php/RevistadaFundarte/index> 30 de março de 2019. 


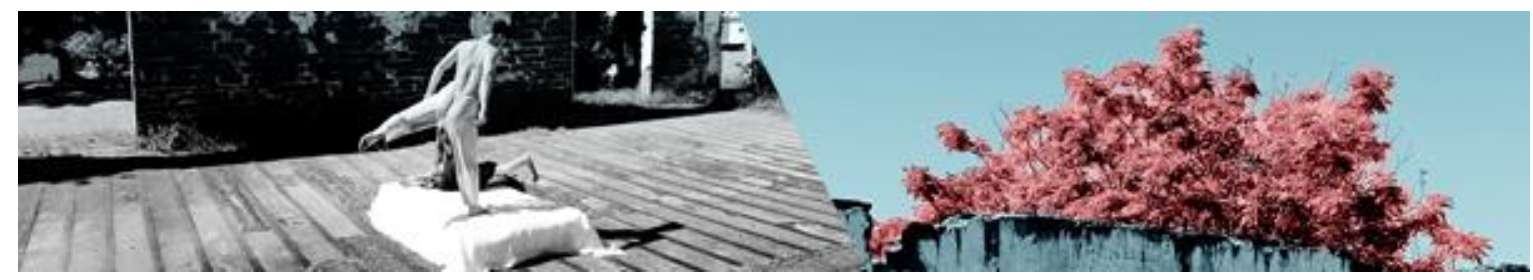

[...] o Tambor de Crioula, manifestação cultural que vem ganhando destaque e visibilidade em sua trajetória, não conta até agora com um volume de pesquisas à altura de sua antiguidade, de sua importância e densidade no conjunto das práticas culturais de tradição afrodescendente no Maranhão. (IPHAN, 2007, pg. 3).

Nas bibliografias relacionadas ao Tambor de Crioula encontram-se descrições sobre a dança. No entanto, essas são breves e genéricas. Nesse artigo, busca-se fazer uma descrição mais esmiuçada do corpo de determinadas mulheres que dançam o Tambor de Crioula no Jamary dos Pretos, a partir de alguns aspectos: as observações durante o Co-habitar com a Fonte no quilombo, a experimentação dessa dança no corpo da primeira autora, o registro em vídeo de alguns trechos da dança e a decodificação dos movimentos junto à segunda autora. Esta decodificação da dança do Tambor de Crioula teve como referência a Estrutura Física do método BPI.

-Mulher 01: apresentava em sua dança os pés com raízes médias, os quais desenhavam um movimento de abrir e fechar para as laterais, empurrando e sugando o chão. Nessa movimentação a mulher percorria a roda e parava diante dos tambores. Suas escápulas movimentavam-se na lateral em relação aos tambores, pontuando os ombros diante deles. Ela tinha uma postura que ia de abaulada para vertical, e nesse momento ocorria em seu corpo uma pontuação do umbigo (punga) no ar, como se saudasse os tamboreiros.

A mulher movimentava a saia como se cobrisse os tambores com ela; suas mãos seguravam-na e faziam movimentos que a deixavam com o formato de um arco passando em cima dos tambores. Ao mover os pés, retirando-os do chão, eles imediatamente voltavam para o piso, como se algo os puxasse de volta, fazendo um movimento acelerado em forma circular diante dos tambores. Nesse momento seu corpo apresentava uma forte tração para o chão, e ela fazia um movimento de sugar com os pés e de levantar a saia com uma das mãos, como se ela puxasse algo do chão com aquela roupa. Ainda nessa dinâmica, ocorria um sutil acento na região do umbigo/baixo ventre. 


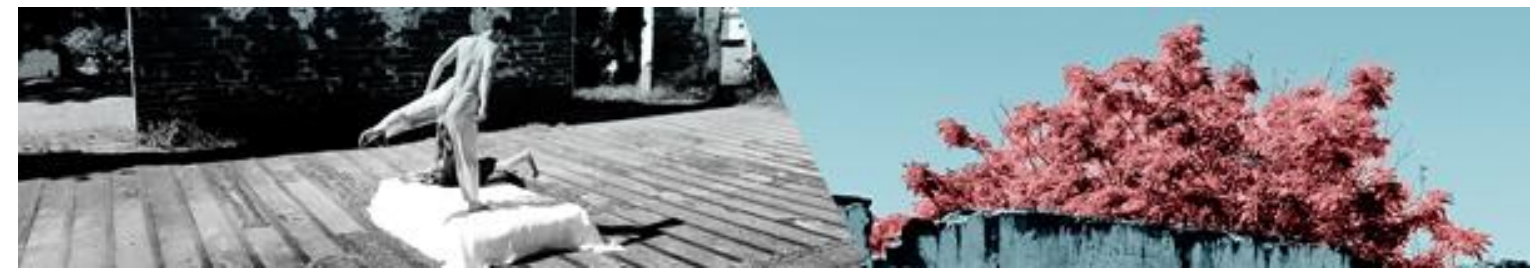

- Mulher 02: seus pés davam pequenos passos para frente ou para trás e quase que deslizavam pelo espaço, com pequenos movimentos de sugar o chão. O fluxo de seu corpo era constante; movimentava-se desenhando um círculo no espaço, a base do seu tronco apoiando-se nas pernas, de modo a ficar "sentada nos ísquios". Em relação ao eixo vertical, o seu tronco estava ora na perpendicular, ora para trás, e quando sua postura alterava, ocorria uma pontuação do umbigo. Ela dançava próxima dos tambores, utilizava principalmente os pequenos apoios dos pés e suas raízes eram profundas.

A mulher segurava a saia sustentando-a à sua frente, deixando suas pernas à mostra, enquanto todo o corpo entrava em movimentos de giros. Em alguns momentos realizava fluxos de giros contínuos, nos quais seu tronco mostrava-se firme, porém com uma pequena oscilação de postura que iniciava por uma inclinação do osso esterno na direção dos tambores.

- Mulher 03: dançando bem perto dos tambores, esta mulher movimentou-se cruzando um pé na frente do outro, fazendo a forma de um quadrado no chão. Seus pés apresentavam raízes soltas e o apoio predominante era o do metatarso. Seu tronco ficava numa postura levemente inclinada para frente, e, nos momentos em que ficava ereto, apresentava uma pontuação firme e precisa do umbigo para com os tambores. Ao entrar em giros, ela segurava sua saia em uma ponta e outra, deixando-a aberta e mostrando suas pernas.

Por vezes, esta mulher percorria o espaço com o comando do quadril, que fazia movimentos pequenos e ágeis, remetendo ao infinito $(\infty)$. Os movimentos de seus pés avançavam, também, em passos miúdos e ligeiros.

- Mulher 04: seus pés eram articulados e apresentavam raízes mais profundas. Em sua dança, realizada de frente para os tambores, a mulher cruzava um pé na frente do outro, formando um quadrado no chão. O pé que saía do chão retornava a ele com um aterramento cada vez maior. Essa mulher segurava uma ponta da saia em 


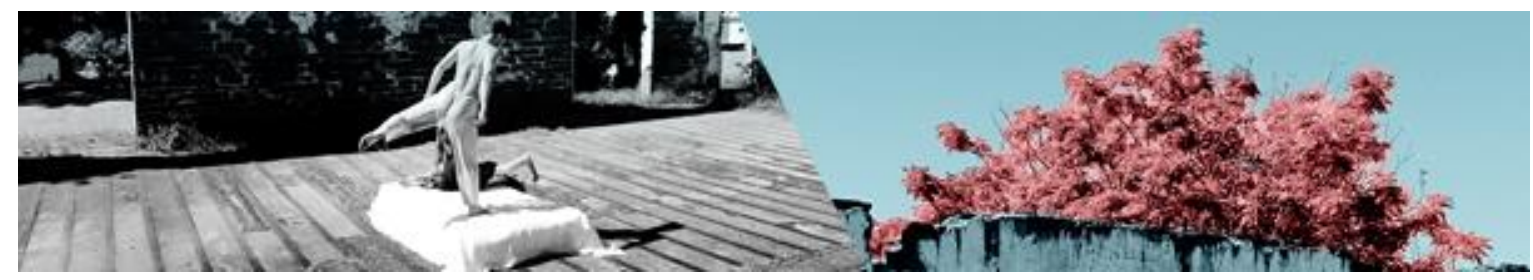

cada mão e passava-a quase que por cima dos tambores. Com a postura na perpendicular, a mulher por vezes aproximava dos tambores, alternadamente, 0 esterno e o umbigo, realizando uma punga diante deles. Sua movimentação apresentava um fluxo de aproximação e distanciamento dos tambores; era como se eles a puxassem para perto.

- Mulher 05: seus pés moviam-se com raízes soltas, eram ágeis e utilizavam seus pequenos apoios. A mulher fazia um desenho de infinito $(\infty)$ com os pés no chão, enquanto seu quadril movimentava-se para as laterais. Segurava a ponta de sua saia com as duas mãos, movendo-a como se cobrisse ou envolvesse os tambores com ela, deixando as pernas à mostra, enquanto seu tronco fazia uma pontuação no espaço com o umbigo (punga), principalmente para a direção dos tambores. Ao entrar em giros, seus pés ganhavam uma maior tração para o chão. Essa mulher seguia um fluxo, em sua dança, de percorrer a roda, passando por todas as pessoas, com os pés ágeis utilizando os pequenos apoios, segurando em sua saia e retornando para perto dos tambores.

- Mulher 06: segurava a ponta da saia com uma das mãos de modo a levantá-la, deixando suas pernas à mostra. Com a saia ela realizava movimentos de infinito $(\infty)$ diante dos tambores. Seus pés movimentavam-se de modo a formar um quadrado no chão; ela utilizava principalmente os grandes apoios dos pés. O pé que ia para frente apresentava uma tração para o chão que reverberava em seu quadril. Este, por sua vez, se movimentava para as laterais. Ao entrar em giros, a mulher elevava um dos joelhos, e, então, marcava o pé no chão, acentuando-o. No giro, uma mão segurava a saia e a outra ficava direcionada para cima.

A partir da pesquisa de campo e das análises empreendidas, conclui-se que existe no Tambor de Crioula dançado pelas mulheres do Jamary, um fluxo, no qual, através do uso das raízes médias, com os pés movimentando-se aceleradamente, elas se aproximam e recuam em relação ao tambor, num movimento quase que 


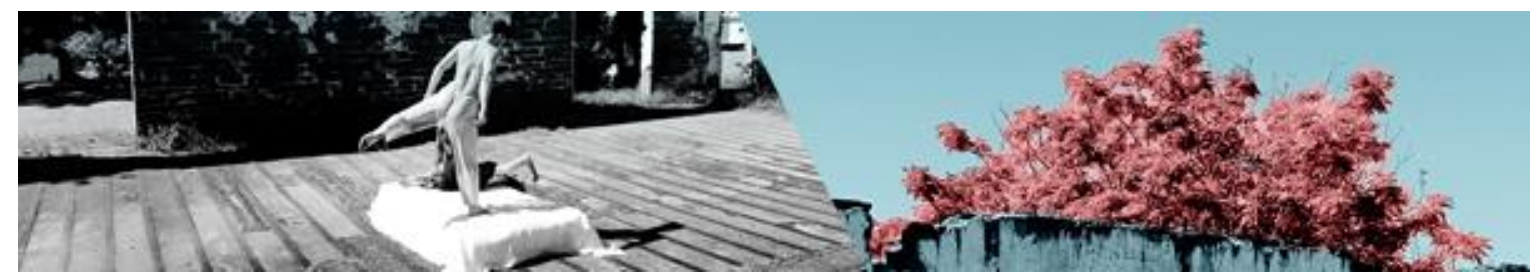

circular em que os pés estão sempre em movimento. Cada mulher que entra para dançar reafirma esse fluxo que vem por meio das várias mulheres, tornando-se quase palpável no espaço. O corpo sente este fluxo quando entra na roda, como a primeira autora pôde sentir quando foi convidada pelas mulheres do Jamary a dançar junto a elas.

O tônus corporal das mulheres não é extremamente elevado. É um tônus médio em que seus pés demonstram um contato com o chão, que vai além da superfície, com passos miúdos e raízes médias que alteram os apoios dos pés ao relacionar-se com o tambor. Suas mãos também acompanham esse tônus, que permite que elas movam a saia fazendo movimentos que remetem a cobrir algo com a vestimenta, passá-la pelo tambor e mostrar parte das pernas.

Ocorre também uma variação de postura do corpo das mulheres, que vai de ereta para abaulada, principalmente quando estão em relação com o tambor. Quando estão abauladas e retornam ao seu eixo, ocorre um acento do umbigo direcionado para o tambor - a punga. Enquanto essas variações de posturas acontecem, o quadril das mulheres movimenta-se fazendo um pequeno e ágil "infinito", que, em alguns momentos, ganha acentos nas laterais.

Os pontos citados acima foram comuns à maioria das mulheres observadas durante o Tambor de Crioula no Jamary dos Pretos. Porém, cada uma delas possui particularidades e diferenças em sua dança. Algumas apresentam um tronco mais enrijecido; outras pontuam mais o apoio dos pés no metatarso ou no calcanhar; enquanto outras mulheres apresentam um movimento de quadril mais evidente e acentuado.

Em síntese, no Tambor de Crioula vivenciado no quilombo Jamary dos Pretos, foram observados uma matriz bem definida de pés ágeis com raízes médias, um fluxo de relação das dançantes com um desenho circular de avanços e recuos com os tambores, uma variação de postura entre vertical e abaulada, um movimento ágil do quadril em "infinito" com acentos nas laterais - que em determinados momentos produz a punga - e a manipulação da saia para compor a sua dança. Ainda que com 


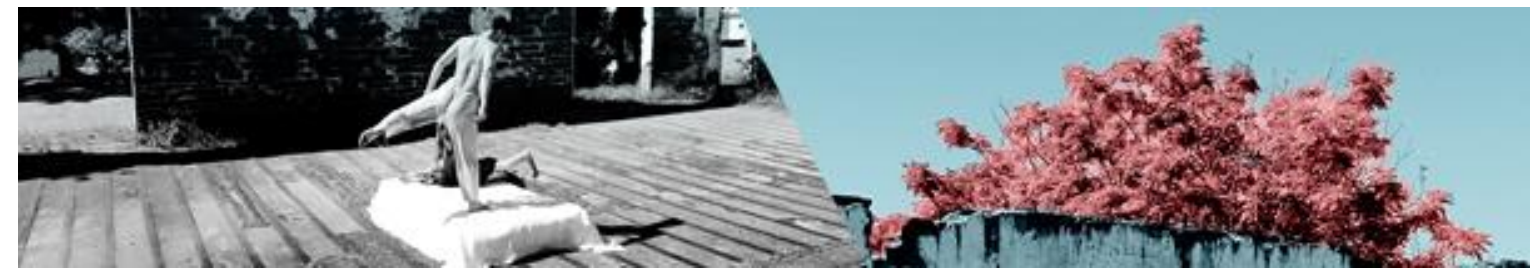

uma matriz definida, cada uma das mulheres possui diferenças no seu modo de dançar, na maneira de segurar a saia e de pungar.

Quando a primeira autora foi convidada pelas mulheres a entrar na roda para dançar, pôde experimentar o som dos tambores ressoando vigorosamente em seus ouvidos. Além disso, foi possível perceber o fluxo de movimentos de aproximação e recuo em relação aos tambores e sentir uma forte necessidade de dançar perto deles. O toque dos tambores dava força e impulso para a dança, que parecia energizar o corpo, propiciando um sentimento de segurança e de liberdade.

Ficou evidente que o elemento "tambor" é o ponto central do Tambor de Crioula. A dança das mulheres segue o ritmo tocado no couro do tambor grande. Foi possível perceber, nessa dança observada em Jamary dos Pretos, a força da sexualidade muito presente, visível na movimentação das mulheres que entravam na roda e dançavam a maior parte do tempo perto dos tamboreiros, realizando movimentos com as saias e com o quadril em relação ao tambor, muitas vezes deixando parte das pernas à mostra e sempre pontuando seu corpo na punga.

\section{Considerações}

O principal foco deste artigo foi trazer uma análise esmiuçada da movimentação presente no Tambor de Crioula, pesquisado na comunidade quilombola Jamary dos Pretos, uma vez que, no geral, faltam descrições dos movimentos das danças de manifestações populares brasileiras, que tratem desses corpos dançantes com mais sutilezas.

No entanto, essa pesquisa de campo foi também parte de um processo de criação artística dentro do método BPI, que trouxe resultados corporais práticos. Desse modo, se faz aqui um breve relato dos resultados ${ }^{5}$ artísticos da pesquisa de campo.

\footnotetext{
${ }^{5}$ Para uma leitura mais profunda sobre os resultados corporais dessa pesquisa, indica-se a leitura da dissertação de mestrado da primeira autora, com orientação da segunda autora: http://repositorio.unicamp.br/bitstream/REPOSIP/330365/1/Alves_MariaJuliaMaranzato_M.pdf

SIMÃO, Maria Julia Maranzato Alves; TURTELLI, Larissa Sato. "Tambores de vida: uma pesquisa do Tambor de Crioula de Jamary dos Pretos a partir do método bailarino-pesquisador-intérprete". . Revista da FUNDARTE, Montenegro, p.91-111, ano 19, ํㅡ 37, Janeiro/Março.

Disponível em: http://.seer.fundarte.rs.gov.br/index.php/RevistadaFundarte/index> 30 de março de 2019.
} 


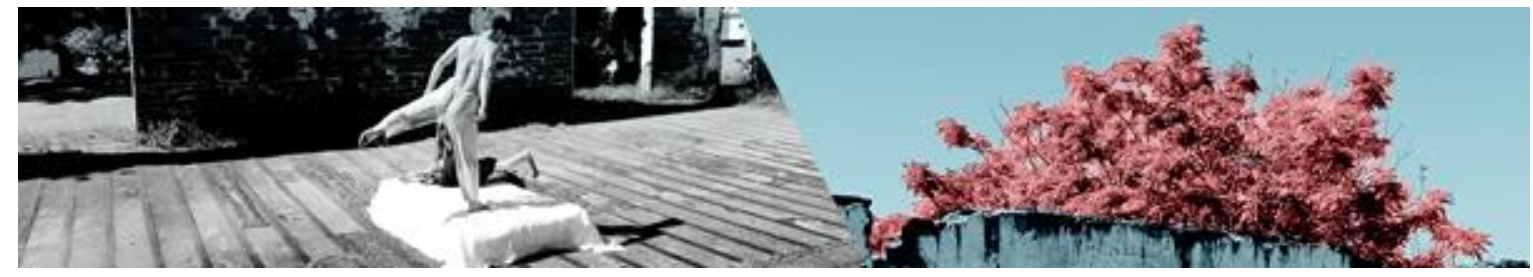

Com o desenvolvimento dos laboratórios dirigidos, realizados após o retorno da pesquisa de campo, durante aproximadamente um ano de trabalho, instaurou-se no corpo da primeira autora uma personagem com o nome de Dalma. A personagem tem como características um quadril grande e pesado para o chão, cabelos curtos, uma voz grossa que dá a sensação da garganta aberta e larga, um púbis pulsante e pés descalços e sujos que penetram e marcam o chão.

Dalma tem em seu corpo um sentido de sexualidade e fertilidade, que ficam claros nos movimentos de báscula do púbis e quadril, em alguns momentos mais curtos, rápidos e bem acentuados, em outros, mais sutis. Esses movimentos despertam em Dalma um corpo fértil ligado a um sentido de renovação e de restauração.

A personagem tem uma profunda conexão com um tambor. É como se Dalma fosse a alma desse tambor, um corpo tambor. No processo artístico foi utilizado um atabaque, o qual foi amplamente trabalhado no corpo da primeira autora, com direção da segunda, de modo a se tornar parte de sua imagem corporal. O corpo da intérprete e o tambor tornavam-se um só; o tambor dançava sendo carregado pela personagem e também era tocado em cena. Em alguns momentos, o som do tambor dava vida para o corpo de Dalma. Em outros, era o movimento pulsante da personagem que dava vida para o tambor, e a junção dos dois revitalizava a terra habitada por ela.

Apesar de ter ocorrido uma negação por parte da intérprete no início do processo de criação, os conteúdos relacionados à sexualidade estavam fortemente presentes em seu corpo, e o campo pesquisado, juntamente com os laboratórios dirigidos, ajudou a despertar tal conteúdo.

Essa sexualidade despertada no corpo da intérprete, a partir do seu encontro com a pesquisa de campo, não estava ligada a uma relação homem-mulher, e sim a uma troca de energias que gerava outros conteúdos no corpo, que o faziam pulsar. A aceitação desse conteúdo por parte da intérprete possibilitou uma liberação do fluxo dos sentidos e, com isso, uma potencialização da modelagem que vinha se instaurando nos laboratórios.

SIMÃO, Maria Julia Maranzato Alves; TURTELLI, Larissa Sato. "Tambores de vida: uma pesquisa do Tambor de Crioula de Jamary dos Pretos a partir do método bailarino-pesquisador-intérprete". . Revista da FUNDARTE, Montenegro, p.91-111, ano 19, ํo 37, Janeiro/Março.

Disponível em: http://.seer.fundarte.rs.gov.br/index.php/RevistadaFundarte/index> 30 de março de 2019. 


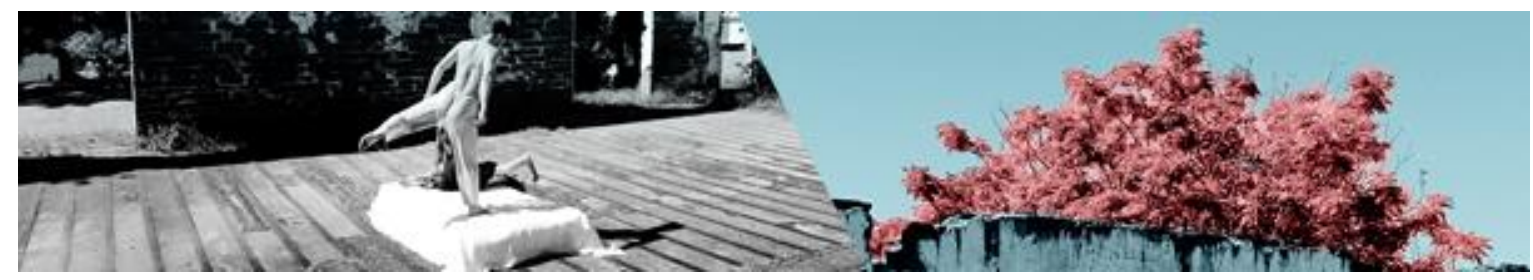

Essa questão da sexualidade, que emergiu do corpo da intérprete, é um ponto importante do Tambor de Crioula. Na pesquisa de campo no quilombo Jamary dos Pretos, as mulheres dançavam diante dos tambores com suas saias levantadas, sendo perceptível haver uma ligação do baixo ventre delas com esses tambores e com o som que eles faziam.

Durante essa pesquisa, notou-se nitidamente a força e a importância que tem o tambor para os moradores de lá. No entanto, foi possível observar a dimensão dessa força apenas quando conteúdos relacionados ao tambor e aos sons que ele produz começaram a aparecer nos laboratórios dirigidos. Foi possível perceber como tocar o tambor, bem como senti-lo no corpo e ouvir seus sons, o que mobilizava o corpo da intérprete, trazendo um fluxo de imagens/sensações/emoções e movimentos que dava passagem para que outros conteúdos emergissem.

No método BPI não há como prever o que será exteriorizado nos corpos dos intérpretes a partir do seu encontro com as pessoas das pesquisas de campo.

Os trabalhos artísticos no método BPI distanciam-se de uma reprodução direta, ou de uma estilização, do que foi pesquisado, pois nesse processo a criação origina-se do encontro de cada intérprete com o campo de pesquisa; encontro este que desencadeia um dinamismo das imagens do intérprete, provindas de sua identidade corporal. (Rodrigues et al. 2016, p.561).

A resultante desse processo artístico foi a personagem Dalma, que no seu percurso de vida traz um rito de fecundidade em seu corpo-tambor que se espraia para todo o espaço. Essa resultante está intimamente ligada à pesquisa de campo realizada e a conteúdos que estavam imanentes no corpo da intérprete. O método BPI favorece que estes conteúdos imanentes venham à tona. E, por estarem fortemente ligados a uma identidade corporal do intérprete, surgem com uma potência que lhes é única. "Tambores de vida" são aqueles que renovam uma força de vida nos corpos dançantes, com liberdade e assunção.

SIMÃO, Maria Julia Maranzato Alves; TURTELLI, Larissa Sato. "Tambores de vida: uma pesquisa do Tambor de Crioula de Jamary dos Pretos a partir do método bailarino-pesquisador-intérprete". . Revista da FUNDARTE, Montenegro, p.91-111, ano 19, no 37, Janeiro/Março.

Disponível em: http://.seer.fundarte.rs.gov.br/index.php/RevistadaFundarte/index> 30 de março de 2019. 


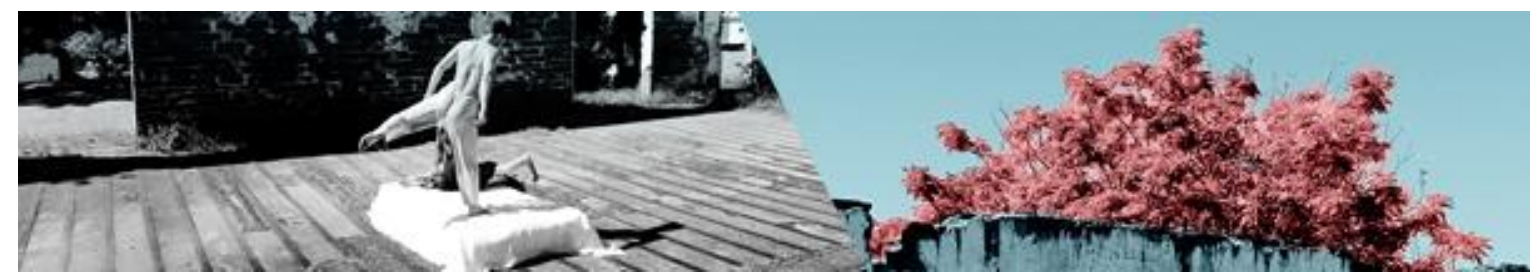

\section{Referências:}

DIAS, P. A outra festa negra. Artigo publicado na coletânea "Festa: Cultura e Sociabilidade na América Portuguesa", FFLCH/USP. São Paulo, Hucitec/Edusp, 2001.

FERRETTI, Sergio F. "Tambor de Crioula”. 1981. Rio de Janeiro: FUNARTE. 1981. FERRETI, S.; SANTOS, M. R. C; SANDLER, P.; PEREIRA, E. CMF - Comissão Maranhense de Folclore, Boletim n 03, 1995.

FIGUEIREDO, Kit e OLIVEIRA, Gabriel. Tambor de Crioula do Maranhão. Disponível em <http://www.youtube.com/watch?v=yhtHsZniylE> .Acesso em 10/10/2016.

IPHAN. Tambor de Crioula: parecer técnico. 2007, 15p. Ministério da Cultura, Brasília, 2007.

O'DWYER, E. C. "Quilombos: identidade étnica e territorialidade". 2002. Rio de Janeiro: Editora FGV. 2002.

PEREIRA, E. A. "Os Tambores estão frios: Herança cultural e sincretismo religioso no ritual de Candombe", 2005. Juiz de fora: Funalfa Edições; Belo Horizonte: Mazza Edições, 2005.

PINHEIRO, A. C. "Terras de Quilombo" para: Projeto Formulação de uma Linguagem Pública sobre Comunidades Quilombolas, 2015. Belo Horizonte- MG.

RAMASSOTE, R. M.; BARROS, V; CORDEIRO R. R. "Os Tambores da Ilha”. 2006. IPHAN. São Luís -M, 2006.

ROCHA. M "Patrimônio imaterial: o Tambor de Crioula". 2014. Revista da Universidade Vale do Rio Verde, Três Corações, v. 12, n. 1, p. 373-380, jan./jul. 2014.

RODRIGUES, G.E.F. "O Método BPI (Bailarino-Pesquisador-Intérprete) e o desenvolvimento da imagem corporal: reflexões que consideram o discurso de bailarinas que vivenciaram um processo criativo baseado neste método". 2003. 171p. Tese (Doutorado em Artes) - Instituto de Artes, Universidade Estadual de Campinas, Campinas, 2003. 